\title{
IMPACT OF DIETARY HUMIC SUBSTANCES SUPPLEMENTATION ON SELECTED MINERALS IN MUSCLES OF BROILER CHICKENS
}

\author{
Skalická, M., Nad', P., Bujňák, L., Marcin, A. \\ Department of Animal Nutrition and Husbandry \\ University of Veterinary Medicine and Pharmacy in Košice, Komenského 73, 04181 Košice \\ Slovakia \\ magdalena.skalicka@uvlf.sk
}

\section{ABSTRACT}

In this study, we assessed the effect of humic substances on the changes of some mineral $(\mathrm{Ca}, \mathrm{Mg}, \mathrm{Cu}$ and $\mathrm{Zn}$ ) content in the thigh and breast muscle of broilers. Group 1 (G1) was supplemented with $0.7 \%$ Humac Natur Mycosorb (HNMy), and G2 with $0.3 \%$ HNMy. The control group (GC) received a basal diet without any supplements. In the breast muscle of broilers from the group G1 we found a statistically significantly higher $(\mathrm{P}<0.05) \mathrm{Ca}$ content and significantly reduced $(\mathrm{P}<0.05)$ in the thigh muscle Ca content from the group G2 compared to the control group (GC). A statistically significant increase in $\mathrm{Mg}$ content $(\mathrm{P}<0.05)$ was analyzed in breast muscles in the group G1 and also significant reduction $(\mathrm{P} \leq 0.01)$ in $\mathrm{Cu}$ in the breast and thigh muscles was found in the group G1 and in the breast muscle from the group G2 compared to the GC. Significantly lower content of $\mathrm{Zn}(\mathrm{P} \leq \mathbf{0 . 0 5})$ was found in the breast and thigh muscles of broilers in the group G2 and strong positive correlation $(r=0.9093)$ were observed between $\mathrm{Ca}$ in breast muscle from the group G2 and Ca in thigh muscle from the control group. A negative correlation ( $r=-0.7656)$ was shown for $\mathrm{Mg}$ between thigh muscle from the group G2 and Ca in thigh muscle from the GC. A strong negative correlation was confirmed $(r=-0.9221)$ for $\mathrm{Zn}$ content in breast muscles between groups G2 and G1. The high positive correlation for $\mathbf{Z n}$ was occurred between breast muscle from the control group and thigh muscle from the group G1 $(r=0.9786)$.

Key words: AAS; broilers; calcium; copper; humic substances; magnesium; zinc

\section{INTRODUCTION}

The nutritional value and the outstanding taste of chicken meat have given rise to an increase in its consumption in a number of countries. Chicken meat is a popular ingredient in our diet, people consume it mainly for its organoleptic qualities (colour, taste), but also for nutritional reasons-full of proteins, vitamins and minerals. This means that the search for the new ways to improve 
the production yield of this animal species is of considerable interest. In recent years, there is growing interest in the use of humic compounds in animal feeding. The supplemental humic substances (HS) as a g warowth-promoting agent has multiple health effects and nutritional benefits for domestic animals [15]. The effect of humic compounds used in animal nutrition on rearing performance improved the results obtained for growth rate, feed utilization, meat quality, egg yield, and egg shell thickness and strength $[1,3,10,16,26]$. Some studies investigated the effect of using humic acids (HA) as growth promoter in poultry and obtained positive results $[9,17]$. Humic substances have shown strong affinity for binding various substances, such as heavy metals [11, 13], minerals [5] and aflatoxins [19, 25]. It has been indicated that HA had differentiated effects upon trace elements in rats. Plasma iron levels were hardly affected, while copper and zinc levels were initially suppressed with a tendency for recovery after 60 days. Feeding humic substances increased levels of some essential minerals (such as $\mathrm{Ca}, \mathrm{Mg}$ and $\mathrm{Fe}$ ) in serum, liver and poultry muscles [22]. There are interactions between the individual chemical elements [2], the mutual manifestation manifests itself synergistically or antagonistically, which takes place in feed, in the digestive tract, as well as in the process of tissue and cellular metabolism.

The aim of this study was to find out the influence of humic substances on the changes of mineral content $(\mathrm{Ca}$, $\mathrm{Mg}, \mathrm{Cu}$ and $\mathrm{Zn}$ ) in the thigh and breast muscle of broiler chickens.

\section{MATERIALS AND METHODS}

One-day-old chickens of hybrid ROSS 308 were randomly divided into 3 groups $(n=30)$. The average body weight of the chickens was $37.30 \mathrm{~g}$. Dietary treatments were as follows: the broilers were fed commercial feed mixture BR1, diet for fattening broilers within 10 days of age, BR2 diet for growing to 30 days of age and BR3 final feed mixture (AGROCASS plus, Ltd. Čaňa, Slovakia) for the duration of the experiment (42 days).

\section{Ethical statement}

The experiment was approved by the Ethics Committee of the University of Veterinary Medicine and Pharmacy in Košice, the Slovak Republic. All procedures in this study were performed in accordance with the principles of the
European Directive on the Protection of Vertebrate Animals Used for Experimental and Other Scientific Purposes (European Parliament and Council, 2010).

\section{Composition of BR1 diet for fattening}

Maize $35.00 \%$; wheat $35.00 \%$; soybean meal $21.30 \%$; dried blood $1.25 \%$; limestone $1.00 \%$; monocalcium phosphate $1.00 \%$; salt $0.10 \%$; lysine $1.20 \%$; methionine $0.60 \%$; premix $0.50 \%$. Chemical composition: metabolic energy $12.01 \mathrm{IU}$; nitrogenous substances $22 \%$; ash $6 \%$; fat $2.5-$ $5.0 \%$; crude fibre max. $4.00 \%$; nonphytate phosporus min. $0.42 \%$; Ca min $0.9 \%$; Na min $0.15 \%$; retinol 12500 IU.kg ${ }^{-1}$; Cholecalciferol 3000 IU.kg-1; alfa-tocoferol 50 IU.kg-1 . Antioxidants: propylgallat $100 \mathrm{mg} \cdot \mathrm{kg}^{-1}$. Coccidiostats: narazin $70 \mathrm{mg} \cdot \mathrm{kg}^{-1}$.

\section{Composition of BR2 diet for growing}

Maize $40 \%$; wheat $35 \%$; soybean meal $18.70 \%$; limestone $1.05 \%$; monocalcium phosphate $0.70 \%$; salt $0.15 \%$; lysine $1.15 \%$; methionine $0.46 \%$; premix $0.50 \%$. Chemical composition: metabolic energy 12.03 IU; nitrogenous substances $19.5 \%$; ash $4-6 \%$; fat 6-8\%; crude fibre max. $4.50 \%$; nonphytate phosphorus min. $0.40 \%$; Ca min. $0.85 \%$; Na min. $0.14 \%$; retinol 12500 IU. kg-1 ; cholecalciferol 3000 IU.kg ${ }^{-1}$; alfa-tocoferol 40 mg. $\mathrm{kg}^{-1}$. Antioxidants: propylgallat $100 \mathrm{mg} \cdot \mathrm{kg}^{-1}$. Coccidiostats: salinomycinat sodium $70 \mathrm{mg} \cdot \mathrm{kg}^{-1}$.

\section{Composition of BR3 final diet}

Maize $37 \%$; wheat $36.80 \%$; soybean meal $20 \%$; limestone $1.12 \%$; monocalcium phosphate $1 \%$; salt $0.20 \%$; lysine $0.98 \%$; methionine $0.40 \%$; premix $0.50 \%$. Chemical composition: metabolic energy 12.37 IU; nitrogenous substances $19 \%$; ash $4-6 \%$; fat $6-10 \%$; crude fibre max. $4.00 \%$; nonphytate phosphorus min. $0.40 \%$; Ca min $0.85 \%$; Na min $0.14 \%$; retinol 10000 IU. $\mathrm{kg}^{-1}$; chol ecalciferol 2000 IU. $\mathrm{kg}^{-1}$; alfa-tocoferol $30 \mathrm{mg} \cdot \mathrm{kg}^{-1}$. Antioxidants: propylgallat $100 \mathrm{mg} \cdot \mathrm{kg}^{-1}$.

The control group (GC) was fed with basal diet without any supplement. The experimental group G1 was supplemented in feed with $0.7 \%$ Humac Natur Mycosorb (HNMy). Group G2 was supplemented in feed with $0.3 \%$ Humac Natur Mycosorb (HNMy). The Humac Natur Mycosorb was obtained from HUMAC Ltd. Košice, Slovakia. 


\section{Composition of Humac Natur Mycosorb}

Powder (particle size up to $100 \mu \mathrm{m}$ ), humic substances $60 \%$, fulvic acid $5 \%$, Ca 42.278 g.kg-1, $\mathrm{Mg} 5.100$ g.kg ${ }^{-1}$, Fe 19.046 g. $\mathrm{kg}^{-1}, \mathrm{Cu} 15 \mathrm{mg} \cdot \mathrm{kg}^{-1}, \mathrm{Zn} 37 \mathrm{mg} \cdot \mathrm{kg}^{-1}, \mathrm{Mn} 442 \mathrm{mg} \cdot \mathrm{kg}^{-1}$, Co $1.24 \mathrm{mg} . \mathrm{kg}^{-1}$, Se $1.67 \mathrm{mg} \cdot \mathrm{kg}^{-1}$, V $42.1 \mathrm{mg} \cdot \mathrm{kg}^{-1}$, Mo $2.7 \mathrm{mg} \cdot \mathrm{kg}^{-1}$.

During fattening chickens had access to water and feed ad libitum. They were reared on deep litter and microclimatic conditions complied with the requirements for fattening of broilers. The temperature was gradually decreased from $33{ }^{\circ} \mathrm{C}$ on day 1 to $21^{\circ} \mathrm{C}$ on day 42 and kept constant afterword. The relative humidity was maintained between $50-70 \%$. After fattening, the animals were stunned and killed by cervical dislocation. Subsequently, breast and thigh muscle samples were taken for further laboratory examination. The muscle samples were immediately frozen and stored at $-20{ }^{\circ} \mathrm{C}$ until analysed. The analysis consisted of digestion ( $5 \mathrm{ml} \mathrm{HNO}_{3}$ and $1 \mathrm{ml} \mathrm{HCl}$ per $1 \mathrm{~g}$ of sample) in a Milestone mineralization system (MLS 1200 Mega) with microwave decomposition technology. Analysis of samples for the presence of calcium, magnesium, copper and zinc was performed on an AAS (Unicam Solar 939, UK) by the flame method (Table 1). The methodology presented in the List of Official Methods and Laboratory Diagnostics of Food and Feed (Bulletin of the Ministry of Agriculture SR, 2004) was used for the determination.

\section{Statistical analysis}

The differences between means were determined, according to the unpaired t-test using GraphPad Prism 6 software. Correlations between pairs of elements in each tissue were determined by Pearson correlation analyses. Some of these correlations were highly influenced by the samples that had undetectable mineral concentrations and only samples with detectable mineral levels were included in the analysis. Only significant correlations with an $r$ value $>0.3$ are reported.

\section{RESULTS AND DISCUSSION}

The values presented in the Tables 2 and 3 are the average values calcium $(\mathrm{Ca})$, magnesium $(\mathrm{Mg})$, copper $(\mathrm{Cu})$ and zinc $(\mathrm{Zn})$ from 6 samples of breast and thigh muscle from each experimental group. The addition of humic substances in feed ensures good animal health and has a positive effect on production parameters and does not require withdrawal periods.

In the breast muscle of broilers from the group G1 we found a statistically significantly higher $(\mathrm{P}<0.05)$ Ca content $\left(0.51 \mathrm{~g} . \mathrm{kg}^{-1}\right)$ compared to the control group

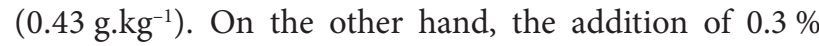
HNMy (G2) to feed significantly reduced $(\mathrm{P}<0.05) \mathrm{Ca}$ content in the thigh muscle $\left(0.32 \mathrm{~g} \cdot \mathrm{kg}^{-1}\right)$ compared to the control group (0.48 g. $\left.\mathrm{kg}^{-1}\right)$, but Ca was slightly increased in the breast muscle $\left(0.47 \mathrm{~g} \cdot \mathrm{kg}^{-1}\right)$. Probably, the low concentration of $\mathrm{Ca}$ in the thigh muscle occurred due to chelating effects of humic substances that are influenced by their large number of carboxylic acid side chains. $\mathrm{M}$ a ri a m et al. [14] found an increased Ca content in poultry meat (1.72 g. $\left.\mathrm{kg}^{-1}\right)$ compared to the values found by us. Similarly, Straková et al. [23] when comparing the nutritional content of broiler and pheasant muscle in both sexes, found that higher levels of $\mathrm{Ca}$ and $\mathrm{Mg}$ in breast muscle (males 2.15; 1.54 g. $\mathrm{kg}^{-1}$ and females $2.03 ; 1.47 \mathrm{~g} . \mathrm{kg}^{-1}$ ) and in thigh muscle (males 1.80; $1.12 \mathrm{~g} . \mathrm{kg}^{-1}$ and females $1.67 ; 1.13 \mathrm{~g} . \mathrm{kg}^{-1}$ ). After feeding humate, increased levels of some essential minerals (such as $\mathrm{Ca}, \mathrm{Mg}, \mathrm{Al}$ and $\mathrm{Fe}$ ) in serum, liver and muscles were recorded by $\mathrm{Stepchenko}$ et al. [22]. The relatively low Ca levels in chicken muscle (13.83 ppm) were

Table 1. Working conditions of atomic absorption spectrometer for analysis of minerals

\begin{tabular}{lccccc}
\hline Element & Fuel & Support & $\begin{array}{c}\text { Flame } \\
\text { stoichiometer }\end{array}$ & $\begin{array}{c}\text { Wavelength } \\
{[\mathrm{nm}]}\end{array}$ & $\begin{array}{c}\text { Spectral band pass } \\
{[\mathrm{nm}]}\end{array}$ \\
\hline Calcium & Acetylene & Air & Oxidizing & 422.7 & 0.5 \\
Magnesium & Acetylene & Air & Oxidizing & 285.2 & 0.5 \\
Copper & Acetylene & Air & Oxidizing & 324.8 & 0.5 \\
Zinc & Acetylene & Air & Oxidizing & 213.9 & 1.0 \\
\hline
\end{tabular}


Table 2. The content of calcium and magnesium in breast and thigh muscle of broilers

\begin{tabular}{cccc}
\hline Group & Muscle & $\begin{array}{c}\mathbf{C a} \\
{\left[\mathrm{g} \cdot \mathrm{kg}^{-1}\right]}\end{array}$ & $\begin{array}{c}\mathbf{M g} \\
{\left[\mathrm{g} \cdot \mathrm{kg}^{-1}\right]}\end{array}$ \\
\hline \multirow{2}{*}{ GC } & Breast & $0.43 \pm 0.07$ & $0.69 \pm 0.08$ \\
& Thigh & $0.48 \pm 0.06$ & $0.67 \pm 0.12$ \\
\hline \multirow{2}{*}{ G1 } & Breast & $0.51 \pm 0.09^{*}$ & $0.80 \pm 0.06^{*}$ \\
& Thigh & $0.51 \pm 0.12$ & $0.59 \pm 0.04$ \\
\hline \multirow{2}{*}{ G2 } & Breast & $0.47 \pm 0.06$ & $0.73 \pm 0.07$ \\
& Thigh & $0.32 \pm 0.06^{*}$ & $0.67 \pm 0.12$ \\
\hline
\end{tabular}

The data are means of 6 samples of breast and thigh muscles from each group; GC—diet without the addition of humic substances; G1 - diet with the addition of $0.7 \%$ Humac Natur Mycosorb; G2 — diet with the addition of $0.3 \%$ Humac Natur Mycosorb; * P $\leq 0.05$

Table 3. The content of copper and zinc in breast and thigh muscle of broilers

\begin{tabular}{cccc}
\hline Group & Muscle & $\begin{array}{c}\mathrm{Cu} \\
{\left[\mathrm{mg} \cdot \mathrm{kg}^{-1}\right]}\end{array}$ & $\begin{array}{c}\text { Zn } \\
{\left[\mathrm{mg}^{\left.-k^{-1}\right]}\right.}\end{array}$ \\
\hline \multirow{2}{*}{$\mathrm{GC}$} & Breast & $11.72 \pm 1.12$ & $26.62 \pm 1.59$ \\
& Thigh & $11.62 \pm 1.18$ & $28.35 \pm 4.05$ \\
\hline \multirow{2}{*}{$\mathrm{G} 1$} & Breast & $8.83 \pm 1.08^{* * *}$ & $25.18 \pm 2.59$ \\
& Thigh & $8.50 \pm 0.77^{* *}$ & $25.75 \pm 3.05$ \\
\hline \multirow{2}{*}{$\mathrm{G} 2$} & Breast & $9.35 \pm 0.62^{* *}$ & $22.45 \pm 2.82^{*}$ \\
& Thigh & $10.07 \pm 0.69$ & $24.38 \pm 2.85^{*}$ \\
\hline
\end{tabular}

The data presented are means of 6 samples of breast and thigh muscles from each group; GC - diet without the addition of humic substances; G1 - diet with the addition of $0.7 \%$ Humac Natur Mycosorb; G2 - diet with the addition of $0.3 \%$ Humac Natur Mycosorb; $-P \leq 0.05 ;{ }^{* *}-P \leq 0.01$

reported by E b e le dike et al. [4]. A statistically significant increase in $\mathrm{Mg}$ content $(\mathrm{P}<0.05)$ was analyzed in breast muscle $\left(0.80 \mathrm{~g} \cdot \mathrm{kg}^{-1}\right)$ in broilers from the group G1 compared to $\mathrm{Mg}$ content in the muscles $\left(0.69 \mathrm{~g} \cdot \mathrm{kg}^{-1}\right)$ of broilers from the control group (Table 2).

Differentiated effects have been shown by humic acids to trace elements, especially copper and zinc [8]. Humates can act as a potent metal chelator, it is possible that HA chelates the extracellular ions of some elements and transfers them to the cells, which can be explained as the reason for the increase in concentration.

Our study reports that concentrations of copper and zinc in muscles after the addition of humates were lower compared to values in muscles in control chickens (Table 3 ). Regarding the essential elements, the average con- centrations of the monitored elements in the muscles of chickens in this study did not exceed the maximum permissible limits.

In the control group of broilers, higher levels of $\mathrm{Cu}$ were found in the breast and thigh muscles $(11.72 ; 11.62 \mathrm{mg}$. $\mathrm{kg}^{-1}$ ) than in the muscles of broilers from the groups G1 (8.83; 8.50 mg. $\left.\mathrm{kg}^{-1}\right)$ and G2 $\left(9.35 ; 10.07 \mathrm{mg} . \mathrm{kg}^{-1}\right)$. A significant reduction in $\mathrm{Cu}$ in the breast and thigh muscles was found in the group G1 $(\mathrm{P} \leq 0.01)$ compared to the control group. A similar significant reduction $(\mathrm{P} \leq 0.01)$ was observed only in breast muscle in the group G2. Copper is an element that presents itself as essential but also potentially toxic. The highest concentrations of copper are found in the liver, lower content in the kidneys and the lowest in muscle. Several authors report lower or nearly equal levels 
Table 4. Correlation coefficients between minerals ( $\mathrm{Ca}, \mathrm{Mg}, \mathrm{Cu}, \mathrm{Zn}$ ) in the breast muscle (BM) and the thigh muscle (TM) in the control group

\begin{tabular}{ccccccccc}
\hline Control & Ca BM & Mg BM & Cu BM & Zn BM & Ca TM & Mg TM & Cu TM & Zn TM \\
\hline Ca BM & 1.0 & -0.1875 & $\mathbf{0 . 8 3 3 3}$ & $\mathbf{0 . 8 1 5 9}$ & 0.4450 & -0.4808 & 0.2157 & 0.3002 \\
Mg BM & - & 1.0 & -0.1481 & -0.4029 & 0.0745 & 0.5084 & 0.2878 & $\mathbf{0 . 7 2 4 8}$ \\
Cu BM & - & - & 1.0 & 0.3919 & 0.0915 & -0.6771 & -0.3028 & 0.2873 \\
Zn BM & - & - & - & 1.0 & 0.6061 & -0.2322 & 0.5566 & 0.0162 \\
Ca TM & - & - & - & - & 1.0 & -0.1211 & 0.6754 & -0.0255 \\
Mg TM & - & - & - & - & - & 1.0 & 0.5623 & 0.4637 \\
Cu TM & - & - & - & - & - & - & 1.0 & 0.3339 \\
Zn TM & - & - & - & - & - & - & - & 1.0 \\
\hline
\end{tabular}

of the $\mathrm{Cu}$ in chicken muscle in Brazil 0.3-3.5 mg. $\mathrm{kg}^{-1}[6]$; in Turkey 0.5 to $12.3 \mathrm{mg} . \mathrm{kg}^{-1} 1$ [24] ; $0.27-0.82 \mathrm{mg} \cdot \mathrm{kg}^{-1}$ in China [7]. S k a l i $\mathrm{k}$ a et al. [18] recorded in the experiment lower levels of $\mathrm{Cu}\left(6.180-7.88 \mathrm{mg} \cdot \mathrm{kg}^{-1}\right)$ in breast and thigh muscle $\left(6.13-6.98 \mathrm{mg} \cdot \mathrm{kg}^{-1}\right)$, where the feed mixture was added with the addition of $0.7 \%$ Humac Natur Monogastric with the addition of formates. After iron and zinc, copper is the third most abundant trace element in the body. In Pakistan, M a r i a m et al.[14] monitored copper and zinc concentrations in some animals and found that all sample values in the study were below than the permissible limits. Poultry muscle recorded the lowest concentrations of copper and zinc (12.86 mg. $\mathrm{kg}^{-1}, 28.52 \mathrm{mg} . \mathrm{kg}^{-1}$, resp.).

In our study we found higher levels of $\mathrm{Zn}$ in the breast and thigh muscles $\left(26.62 ; 28.35 \mathrm{mg} \cdot \mathrm{kg}^{-1}\right)$ than in the muscles of broilers from the groups G1 and G2. The significantly lower content of $\mathrm{Zn}(\mathrm{P} \leq 0.05)$ was found in the breast and thigh muscle of broilers from the group G2 (22.45; $\left.24.38 \mathrm{mg} \cdot \mathrm{kg}^{-1}\right)$ compared to the control group. A decrease in $\mathrm{Zn}$ levels in the breast and thigh muscles was also observed in the group G1. K h a n et al. [12] found much higher values in the thigh muscle (107.4 \pm 7.60 ; $106.6 \pm 7.37$ and $\left.106.78 \pm 7.48 \mathrm{mg} \cdot \mathrm{kg}^{-1}\right)$ and breast muscle $\left(107.82 \pm 7.66 ; 107,4 \pm 7.49\right.$ and $\left.107.95 \pm 7.73 \mathrm{mg} \cdot \mathrm{kg}^{-1}\right)$ taken from three different districts. $\mathrm{H} u$ et al. [7] found $\mathrm{Zn}$ values of $3.27-17.90 \mathrm{mg} \cdot \mathrm{kg}^{-1}$ in the poultry muscle from the food markets region in southern China.

Correlation analysis revealed some relationships between the content of elements in breast and thigh muscles (Table 4).
In the control group, correlations were observed in the breast muscle between $\mathrm{Ca}$ and $\mathrm{Zn}(\mathrm{r}=0.8159)$ and between $\mathrm{Ca}$ and $\mathrm{Cu}(\mathrm{r}=0.8333)$. Similarly, positive correlation was observed between $\mathrm{Zn}$ in the thigh muscle and $\mathrm{Mg}$ in the breast muscle $(r=0.7248)$. A negative correlation was found for $\mathrm{Mg}$ in the thigh muscle and $\mathrm{Cu}$ in the breast muscle $(r=-0.6771)$.

The effect of different addition levels of Humac substances on the correlation coefficients of mineral elements in the breast and thigh muscles are shown in Tables 5 and 6 .

The calcium content in the breast muscle confirmed a strong positive correlation between the control group and the group G2 $(r=0.7195)$. The strong positive correlation $(r=0.9093)$ for Ca was found in the thigh muscle from the control group and in the breast muscle from the group G2. On the other hand, in the group G2, the medium negative correlation was shown $(\mathrm{r}=-0.6724)$ for $\mathrm{Mg}$ between thigh muscle and breast muscle. Similarly, significantly negative correlation ( $r=-0.7656)$ was found between in the thigh muscles, between $\mathrm{Mg}$ from the group G2 and Ca from the control group. A high positive correlation $(r=0.7643)$ were observed in the thigh muscles between $\mathrm{Mg}$ content from group G1 and Ca content from the control group.

Other studies examined the relationship between mineral concentrations, and the relationship of mineral concentration physicochemical characteristics in muscles of Japanese Black steers. Magnesium (Mg), potassium (K) and zinc $(\mathrm{Zn})$ concentrations had negative correlations with fat content, but sodium $(\mathrm{Na})$, manganese $(\mathrm{Mn})$, copper $(\mathrm{Cu})$ and molybdenum (Mo) concentrations were not correlated with fat content. The results of the present experiment sug- 
Table 5. Correlation coefficients between $\mathrm{Ca}$ and $\mathrm{Mg}$ in experimental groups in the breast muscle (BM) and the thigh muscle (TM)

\begin{tabular}{|c|c|c|c|c|c|c|c|c|c|c|c|c|}
\hline & & \multicolumn{3}{|c|}{ GC } & \multicolumn{4}{|c|}{ G1 } & \multicolumn{4}{|c|}{ G2 } \\
\hline & & Са ТM & Mg BM & Mg TM & $\mathrm{Ca} \mathrm{BM}$ & Са ТM & $\mathrm{Mg} \mathrm{BM}$ & Mg TM & $\mathrm{Ca} \mathrm{BM}$ & Са TM & Mg BM & Mg TM \\
\hline \multirow{4}{*}{ GC } & $\mathrm{Ca} \mathrm{BM}$ & 0.4450 & -0.1875 & -0.4808 & -0.2282 & 0.0878 & 0.5815 & 0.1301 & 0.7195 & 0.6928 & -0.0468 & -0.3848 \\
\hline & Са TM & 1.0 & 0.0745 & 0.1211 & -0.4361 & -0.5810 & 0.5292 & 0.7643 & 0.9093 & -0.0296 & 0.5504 & -0.7656 \\
\hline & Mg BM & - & 1.0 & 0.5084 & -0.4079 & -0.2611 & -0.1884 & -0.2331 & 0.3581 & 0.1949 & 0.6002 & -0.4305 \\
\hline & Mg TM & - & - & 1.0 & -0.6571 & 0.3087 & -0.2331 & -0.1622 & 0.0193 & -0.3916 & 0.7616 & -0.4236 \\
\hline \multirow{4}{*}{ G1 } & Ca BM & - & - & - & 1.0 & -0.2879 & -0.5541 & 0.2185 & 0.1579 & -0.1822 & -0.1406 & -0.2687 \\
\hline & Са TM & - & - & - & - & 1.0 & 0.1663 & 0.0030 & -0.5112 & -0.0556 & -0.4483 & 0.4957 \\
\hline & $\mathrm{Mg} \mathrm{BM}$ & - & - & - & - & - & 1.0 & 0.5775 & -0.4199 & -0.1343 & 0.3848 & -0.2887 \\
\hline & Mg TM & - & - & - & - & - & - & 1.0 & -0.5853 & 0.0318 & -0.0911 & -0.4236 \\
\hline \multirow{3}{*}{ G2 } & Ca BM & - & - & - & - & - & - & - & 1.0 & 0.1869 & 0.6189 & -0.4726 \\
\hline & Са TM & - & - & - & - & - & - & - & - & 1.0 & -0.2383 & -0.2407 \\
\hline & Mg BM & - & - & - & - & - & - & - & - & - & 1.0 & -0.6724 \\
\hline
\end{tabular}

GC-control group; G1—diet with the addition of $0.7 \%$ Humac Natur Mycosorb; G2-diet with the addition of $0.3 \%$ Humac Natur Mycosorb

Table 6. The correlation coefficients between $\mathrm{Cu}$ and $\mathrm{Zn}$ in experimental groups in the breast muscle (BM) and the thigh muscle (TM)

\begin{tabular}{|c|c|c|c|c|c|c|c|c|c|c|c|c|}
\hline & & \multicolumn{3}{|c|}{ GC } & \multicolumn{4}{|c|}{ G1 } & \multicolumn{4}{|c|}{ G2 } \\
\hline & & Cu TM & Zn BM & Zn TM & Cu BM & Cu TM & Zn BM & Zn TM & $\mathrm{Cu} B M$ & Cu TM & Zn BM & Zn TM \\
\hline \multirow{4}{*}{ GC } & Cu BM & -0.3028 & 0.3919 & 0.2873 & -0.3693 & -0.6987 & 0.7110 & 0.2207 & 0.4947 & 0.5946 & -0.7570 & -0.1164 \\
\hline & Cu TM & 1.0 & 0.5566 & 0.3339 & -0.1777 & -0.0438 & -0.7415 & 0.7003 & -0.1334 & -0.6652 & 0.5717 & -0.1182 \\
\hline & Zn BM & - & 1.0 & 0.0162 & -0.3813 & -0.1836 & -0.1108 & 0.9786 & 0.0519 & 0.1456 & 0.0300 & -0.3661 \\
\hline & Zn TM & - & - & 1.0 & 0.1577 & -0.8666 & -0.2526 & 0.0235 & -0.0108 & -0.5038 & 0.0691 & -0.1198 \\
\hline \multirow{4}{*}{ G1 } & Cu BM & - & - & - & 1.0 & -0.0719 & -0.4372 & -0.3850 & -0.5413 & -0.1427 & 0.3780 & 0.0054 \\
\hline & Cu TM & - & - & - & - & 1.0 & 0.1395 & -0.2734 & -0.2188 & 0.0149 & 0.3357 & 0.0972 \\
\hline & Zn BM & - & - & - & - & - & 1.0 & -0.0907 & 0.6415 & 0.8109 & -0.9221 & 0.2245 \\
\hline & Zn TM & - & - & - & - & - & - & 1.0 & -0.0207 & -0.0302 & 0.1907 & -0.3661 \\
\hline \multirow{3}{*}{ G2 } & Cu BM & - & - & - & - & - & - & - & 1.0 & 0.4836 & -0.8403 & 0.7301 \\
\hline & Cu TM & - & - & - & - & - & - & - & - & 1.0 & -0.7852 & 0.2258 \\
\hline & Zn BM & - & - & - & - & - & - & - & - & - & 1.0 & -0.4701 \\
\hline
\end{tabular}

GC-control group; G1-diet with the addition of $0.7 \%$ Humac Natur Mycosorb; G2-diet with the addition of $0.3 \%$ Humac Natur Mycosorb 
Table 7. Correlation coefficients between minerals ( $\mathrm{Ca}, \mathrm{Mg}, \mathrm{Cu}$ and $\mathrm{Zn}$ ) in experimental group $\mathrm{G} 1$ in the breast muscle (BM) and the thigh muscle (TM)

\begin{tabular}{ccccccccc}
\hline & Ca BM & Mg BM & Cu BM & Zn BM & Ca TM & Mg TM & Cu TM & Zn TM \\
\hline Ca BM & 1.000 & -0.5541 & -0.4731 & 0.5100 & -0.2879 & 0.2185 & 0.7377 & -0.1839 \\
Mg BM & - & 1.000 & -0.0731 & -0.1465 & 0.1663 & 0.5775 & -0.4301 & 0.6523 \\
Cu BM & - & - & 1.000 & -0.4372 & 0.7905 & -0.5029 & -0.0719 & -0.385 \\
Zn BM & - & - & - & 1.000 & -0.0443 & 0.1395 & -0.1530 & -0.0907 \\
Ca TM & - & - & - & - & 1.000 & 0.0030 & -0.0420 & -0.4738 \\
Mg TM & - & - & - & - & - & 1.000 & 0.2620 & 0.3385 \\
Cu TM & - & - & - & - & - & - & 1.000 & -0.2734 \\
Zn TM & - & - & - & - & - & - & - & 1.000 \\
\hline
\end{tabular}

G1—diet with the addition of $0.7 \%$ Humac Natur Mycosorb

Table 8. Correlation coefficients between minerals ( $\mathrm{Ca}, \mathrm{Mg}, \mathrm{Cu}$ and $\mathrm{Zn}$ ) in experimental group $\mathrm{G} 2$ in the breast muscle (BM) and the thigh muscle (TM)

\begin{tabular}{ccccccccc}
\hline & Ca BM & Mg BM & Cu BM & Zn BM & Ca TM & Mg TM & Cu TM & Zn TM \\
\hline Ca BM & 1.000 & 0.6189 & -0.8349 & 0.6496 & 0.1869 & -0.4726 & -0.2770 & -0.9277 \\
Mg BM & - & 1.000 & -0.3096 & 0.2136 & -0.2383 & -0.6724 & 0.0977 & -0.6988 \\
Cu BM & - & - & 1.000 & -0.8403 & -0.4381 & 0.1597 & 0.4836 & 0.7301 \\
Zn BM & - & - & - & 1.000 & 0.8228 & -0.3821 & -0.7852 & -0.4701 \\
Ca TM & - & - & - & - & 1.000 & -0.2407 & -0.8698 & 0.0345 \\
Mg TM & - & - & - & - & - & 1.000 & 0.0636 & 0.2970 \\
Cu TM & - & - & - & - & - & - & 1.000 & 0.2258 \\
Zn TM & - & - & - & - & - & - & - & 1.000 \\
\hline
\end{tabular}

G2_ diet with the addition of $0.3 \%$ Humac Natur Mycosorb

gest that mineral concentrations reflect some traits such as fat content but also the composition of myofiber type and the intracellular fluid volume in the muscle [11].

As regards the trace metals, a strong negative correlation was confirmed $(r=-0.9221)$ for $\mathrm{Zn}$ content in breast muscle between the groups G2 and G1. A strong positive correlation was observed also between $\mathrm{Zn}$ in the breast muscle from the group $\mathrm{G} 1$ and $\mathrm{Cu}$ in the thigh muscle from the group G2 ( $r=0.8109)$. Similarly, positive correlation was demonstrated between $\mathrm{Zn}$ content in thigh muscle from the groups $\mathrm{G} 1$ and $\mathrm{Zn}$ content in breast muscle from the control group $(r=0.9786)$. In the group $G 2$ was found positive correlation $(\mathrm{r}=0.7301)$ between $\mathrm{Cu}$ content in the breast muscle and $\mathrm{Zn}$ content in the thigh muscle and high negative correlation $(r=-0.8403)$ in the breast muscle between $\mathrm{Zn}$ content and $\mathrm{Cu}$ content in the breast muscle.

S k a l i c ká et al. [20] showed significant correlation between minerals in the liver and thigh muscle. The negative correlation was confirmed between $\mathrm{Cd}$ in muscle and $\mathrm{Cr}$ in muscle $(\mathrm{r}=-0.947)$ and $\mathrm{Cu}$ in liver and $\mathrm{Cd}$ in muscle $(r=-0.885)$. The results of this study demonstrate antagonism among selected elements.

In addition, significant correlations were observed between copper and most essential elements in breast and thigh muscles of broiler chickens. Tables 7 and 8 summarise the correlation analysis between minerals in breast and 
thigh muscles in experimental groups G1 and G2.

After addition of $0.7 \%$ HNMy to diet we observed a strong positive correlation between $\mathrm{Cu}$ content in the breast muscle and Ca content in the thigh muscle $(\mathrm{r}=0.7905)$. Also between $\mathrm{Cu}$ content in the thigh muscle and $\mathrm{Ca}$ in the breast muscle $(\mathrm{r}=0.7377)$. S k a l i c k á et al. [21] in the study with addition $0.7 \%$ Humac Natur in the diet for broiler chickens were found negative correlation between the elements: $\mathrm{Ca}$ and $\mathrm{Cu}(\mathrm{r}=-0.6582)$ in the breast muscle.

On the contrary, after addition of $0.3 \%$ HNMy to the diet we observed negative correlations in the thigh muscle between copper and calcium $(\mathrm{r}=-0.8698)$. A strong negative correlation was observed between $\mathrm{Zn}$ content in the thigh muscle and Ca content in the breast muscle $(\mathrm{r}=-0.9277)$. On the other hand, in the study with $0.5 \%$ Humac Natur in the diet there was a positive correlation between $\mathrm{Cu}$ in the thigh muscle and $\mathrm{Ca}$ in the breast muscle $(r=0.8881)[21]$.

\section{CONCLUSIONS}

Increased attention as an alternative to feeding antibiotics in poultry production has been paid to ecological additives. Organic additives are more acceptable by consumers. According to the results of this experiment, the use of the $0.7 \%$ and $0.3 \%$ Humac Natur Mycosorb as feed supplement contributed to the increase in the $\mathrm{Ca}$ and $\mathrm{Mg}$ content in the breast and thigh muscles of broilers. Changes in concentrations of elements observed in the muscle of chickens after the addition of humates included in this study were caused by mutual interactions. The mechanism involves formation of chelate bonds with the elements. To sum up, the Humac Natur can be considered a good feed supplement which positively affects the nutritional value of chicken meat.

\section{ACKNOWLEDGEMENTS}

This study was supported by the project VEGA No. 1/ 0402/20.

\section{CONFLICT OF INTEREST}

The authors declare that there is no conflict of interest.

\section{REFERENCES}

1. Agazzi, A., Cigalino, G., Mancin, G., Savoini, G., Dell' Orto V., 2007: Effects of dietary humates on growth and an aspect of cell-mediated immune response in newborn kids. Small Rumin. Res., 72, 242-245. DOI: 10.1016/j.smallrumres.2006.10.020.

2. Andreji, J., Stráňai, I., Massanyi, P., Valent, M., 2005: Concentration of selected metals in muscle of various fish species. J. Environ. Sci. Health, Part A: Toxic/Hazardous Substances and Environmental Engineering, 40, 899-912. DOI: 10.1081/ ESE-200048297.

3. Dobrzański, Z., Trziszka, T., Herbut, E., Krawczyk, J., Tronin, P., 2009: Effect of humic preparations on productivity and traits of eggs from Greenleg Partridge hens. Ann. Anim. Sci., 9, 165-174.

4. Ebeledike, E. U., Nwokedi, G. I. C., Ndu, O. O., Okoye, F. B. C., Ochiogu, I. S., 2010: Calcium and phosphorus contents of body parts of some domestic animal used as meat source in Nigeria. Asian Pac. J. Trop. Med., 3, 395-398. DOI: 10.1016/S1995-7645(10)60096-X.

5. Elfarissi, F., Pefferkorn, E., 2000: Kaolinite/humic acid interaction in the presence of aluminium ion. Col Surf A: Physicochem. Engin. Aspects, 168, 1-12.

6. Ferreira, K. S., Gomes, J. C., Chaves, J. B. P., 2005: Copper content of commonly consumed food in Brazil. Food Chem., 92, 29-32. DOI: 10.1016/j.foodchem.2004.07.004.

7. Hu, Y., Zhang, W., Chen, G., Chen, H., Tao, S., 2018: Public health risk of trace metals in fresh chicken meat products on the food markets of a major production region in southern China. Environ. Pollut., 234, 667-676. DOI: 10.1016/j.envpol. 2017.12.006

8. Islam, K. M. S., Schumacher, A., Gropp, J. M., 2005: Humic acid substances in animal agriculture. Pakistan J. Nutr., 4, 126-134. DOI:10.1.1.1086.8724\&rep=rep1\&type=pdf.

9. Kamel, M. M., El Hady, M., El Iraqi, K. G., Wahba, F., 2015: Biological immune stimulants effects on immune response, behavioural and productive performance of broilers. Egypt. Poult. Sci. J., 35, 691-702.

10. Karaoglu, M., Macit, M., Esenboga, N., Durdag, H., Turgut, L., Bilgin, O. C., 2004: Effect of supplemental humate 
at different levels on the growth performance, slaughter and carcass traits of broilers. Int. J. Poultry Sci., 3, 406-410. DOI: 10.1.1.556.147\&rep=rep1\&type=pdf.

11. Kitagawa, T., Funaba, M., Matsui, T., 2018: Relationships between mineral concentrations and physicochemical characteristics in the Longissimus thoracis muscle of Japanese Black cattle. Anim. Sci. J., 89, 211-218. DOI: 10.1111/asj. 12919.

12. Khan, Z., Sultan, A., Khan, R., Khan, S., Farah, I, Farah, K., 2016: Concentrations of heavy metals and minerals in poultry eggs and meat produced in Khyber Pakhutunkhwa, Pakistan. Meat Sci. Vet. Pub. Health, 1, 4-10.

13. Madroňová, L., Kozler, J., Cezikova, J., Novák, J., János, P., 2001: Humic acids from coal of the North-Bohemia coal field. III. Metal-binding properties of humic acids measurements in a column arrangement. React. Funct. Polym., 47, 119-123. DOI: 10.1016/S1381-5148(00)00077-8.

14. Mariam, I., Iqbal, S., Nagra, S. A., 2004: Distribution of some trace and macrominerals in beef, mutton and poultry. Int. J. Agric. Biol., 6, 816-820.

15. Ozturk, E., Ocak, N., Turan, A., Erener, G., Altop, A., Cankaya, S., 2012: Performance, carcass, gastrointestinal tract and meat quality traits, and selected blood parameters of broilers fed diets supplemented with humic substances. J. Sci. Food Agric., 92, 59-65. DOI: 10.1002/jsfa.4541.

16. Rath, N. C., Huff, W. E., Huff, G. R., 2006: Effects of humic acid on broiler chickens. Poult. Sci., 85, 410-414. DOI: 10. 1093/ps/85.3.410.

17. Sahin, A., Iskender, H., Terim, K. K., Altinkaynak, K., Hayirli, A., Gonultas, A., Kaynar, O., 2016: The effect of humic acid substances on the thyroid function and structure in lead poisoning. Rev. Bras. Cienc. Avic., 18, 649-654. DOI: 10. 1590/1806-9061-2016-0299.

18. Skalická, M., Nad', P., Bujňák, L., Marcin, A., 2019: Mineral muscle composition of broilers after application of humic substances. In Proceedings Animal Health, Quality of Food and Feed, Košice, 37-39.
19. Skalická, M., Koréneková, B., 2016: The effects of sodium humate and aflatoxin B1 on body weight of broiler chicks. Iran. J. Appl. Anim. Sci., 6, 415-421.

20. Skalická, M., Koréneková, B., Nad', P., 2008: Distribution of trace elements in liver and muscle of Japanese quails. Slovak J. Anim. Sci., 41, 187-189.

21. Skalická, M., Nad', P., Bujňák, L., Hudák, M., 2019: Effects of humic subsstances on the mineral composition of chicken meat. Anim. Husb. Dairy Vet. Sci., 3, 1-5. DOI: 10.15761/ AHDVS.1000168.

22. Stepchenko, L. M., Zhorina, L. V., Kravtsova, L. V., 1991: The effect of sodium humate on metabolism and resistance in highly productive poultry. Nauchnye Doki. Vyss. Shkoly Biol. Nauki, 10, 90-95.

23. Straková, E., Suchý, P., Karásková, K., Jámbor, M., Navrátil, P., 2011: Comparison of nutritional values of pheasant and broiler chicken meats. Acta Vet. Brno, 80, 373-377. DOI: 10. 2754/avb201180040373.

24. Uluozlu, O. D., Tuzen, M., Mendil, D., Soylak, M., 2009: Assessment of trace element contents of chicken products from Turkey. J. Hazard. Mater., 163, 982-987. DOI: 10.1016/j. jhazmat.2008.07.050.

25. Van Rensburg, C. J., Van Rensburg, C. E. J., Van Ryssen, J. B. J., Casey, N. H., Rottinghaus, G. E., 2006: In vitro and in vivo assessment of humic acid as an aflatoxin binder in broiler chickens. Poult. Sci., 85, 1576-1583. DOI: 10.1093/ ps/85.9.1576.

26. Wang, Q., Chen, Y. J., Yoo, J. S., Kim, H. J., Cho, J. H., Kim, I. H., 2008: Effects of supplemental humic substances on growth performance, blood characteristics and meat quality in finishing pigs. Livest. Sci., 117, 270-274. DOI: 10.1016/j. livsci.2007.12.024.

Received June 22, 2021

Accepted August 17, 2021 